f. med. Genet. (1967). 4, 258.

\title{
A Sex Chromatin Survey of Newborn Children in Two London Hospitals
}

\author{
ANGELA I. TAYLOR and ELIZABETH C. MOORES*
}

\author{
From the Paediatric Research Unit, Guy's Hospital Medical School, London S.E.1
}

Liveborn children delivered at Queen Charlotte's Hospital were studied between February 1962 and July 1963 and those born at Guy's from February 1962 onwards.

A group of 9688 babies has been studied to date, comprising 4754 girls and 4934 boys. The sex chromatin findings (based on thionine or Feulgen stained oral smears) are presented in Table $\mathrm{I}$, where they are also compared with published data (Moore, 1959; Bergemann, 1961; Wiesli, 1962; Maclean, Harnden, Court Brown, Bond, and Mantle, 1964; Marden, Smith, and McDonald, 1964). In view of the difficulty of following up some of these children, this report does not include clinical summaries or complete chromosome studies.

Among the $\mathbf{4 7 5 4}$ girls, 5 were chromatin negative; 3 still await follow-up; the remaining 2 were found to have XY sex chromosomes. One case presented with inguinal hernias which were found at operation and by subsequent histological studies to contain testes. This child is a presumptive case of testicular feminization. The other XY female was found to have lipoid adrenal hyperplasia-a very rare condition due to a recessive gene which may cause feminization of a male foetus (O'Doherty, 1964). Two girls had two sex chromatin masses in a proportion of cells and are presumptive XXX females.

Among the 4934 boys, 11 had cells containing single sex chromatin masses. One boy had a proportion of cells with two masses. Of the 11 with single masses, 2 had Down's syndrome (mongolism), and the remaining 9 were clinically normal. One of these 9 was a twin: he and his co-twin, a girl, were born prematurely with birthweights of only $1330 \mathrm{~g}$. and 1275 g., respectively; both were clinically normal and both died at 1 day of age due to immaturity.

Received March 9, 1967.

* Present address: Institute of Cardiology, 35 Wimpole Street, London W.1.
Chromosome studies on four of these children to date show that one has 48 chromosomes with 21 trisomy and XXY, two are XXY, and one is an XY/ XXY mosaic. The boy with a proportion of cells with two masses appeared normal at birth and has yet to be followed up.

Combination of data from six surveys (Table I) enables the incidence of various conditions at birth to be assessed (Table II). Testicular feminization and lipoid adrenal hyperplasia both occur with a frequency of 1 in 23,229 male births or 1 in 45,297 total births. These estimates may well be too high, as Jagiello and Atwell (1962) assess the incidence of testicular feminization in older children as 1 in 62,400 males. There is no estimate of the incidence of lipoid adrenal hyperplasia, though in view of the reported high proportion of consanguinity among the parents it may well be extremely rare.

Double trisomy, $\mathrm{G}_{21} / \mathrm{XXY}$, occurs with a frequency of 1 in 11,614 male births, which is considerably higher than would be expected by the chance association of the two conditions (Hamerton, Giannelli, and Polani, 1965). The findings in trisomy-18 are similar (Taylor, 1967). Among newborns with this condition, 1 of 2 boys had XXY sex chromosomes, and 1 of 14 girls had XXX sex chromosomes. A search of the published reports (Taylor, 1967) reveals that 3 out of 89 trisomy-18 females were XXX and 3 out of 21 trisomy-18 males were XXY. If the frequency of trisomy-18 is taken at about 1 in 4000 live births, this suggests an incidence in the general population of approximately 1 in 100,000 births for $\mathrm{XXX} / 18$ trisomic subjects and approximately 1 in 20,000 for the XXY/18 trisomic state. The incidence of the commoner sex chromosome anomalies agrees with the figure previously recorded (Brown, Buckton, Jacobs, and Tough, 1964). This is the first assessment of the incidence of males with two sex chromatin masses in the general population ( 1 in 23,229) males, all the previous cases having been ascertained in surveys of mental institutions. 
TABLE I

FINDINGS IN SIX HOSPITAL NEWBORN SEX CHROMATIN SURVEYS

\begin{tabular}{|c|c|c|c|c|c|c|c|}
\hline \multirow{2}{*}{ Survey } & \multicolumn{2}{|c|}{ No. Studied } & \multicolumn{2}{|c|}{$\begin{array}{c}\text { Chromatin } \\
\text { Negative Females }\end{array}$} & \multirow{2}{*}{$\begin{array}{c}\text { Chromatin } \\
\text { Positive Females } \\
\text { with Two } \\
\text { Masses }\end{array}$} & \multirow{2}{*}{$\begin{array}{c}\text { Chromatin } \\
\text { Positive Males } \\
\text { with Single } \\
\text { Masses }\end{array}$} & \multirow{2}{*}{$\begin{array}{c}\text { Chromatin } \\
\text { Positive Males } \\
\text { with Two } \\
\text { Masses }\end{array}$} \\
\hline & Female & Male & XY & $\begin{array}{c}\text { XO or } \mathrm{XO} / \mathrm{Xx} \text { or } \\
\text { Chromosomes } \\
\text { Not Examined }\end{array}$ & & & \\
\hline $\begin{array}{l}\text { Moore (1959) } \\
\text { Bergemann (1961) } \\
\text { Wiesli (1962) } \\
\text { Maclean et al. (1964) } \\
\text { Marden et al. (1964) } \\
\text { This report: QCH } \\
\text { „ ", : Guy's }\end{array}$ & $\begin{array}{r}1804 \\
1838 \\
1466 \\
10,000 \\
2206 \\
2184 \\
2570\end{array}$ & $\begin{array}{r}1911 \\
1890 \\
1563 \\
10,725 \\
2206 \\
2317 \\
2617\end{array}$ & $\begin{array}{l}1 \\
1\end{array}$ & $\begin{array}{l}1 \\
4\end{array}$ & $\begin{array}{r}12 \\
1 \\
1 \\
1\end{array}$ & $\begin{array}{r}5 \\
4 \\
1 \\
18 \\
7 \\
3 \\
8\end{array}$ & 1 \\
\hline Total & 22,068 & 23,229 & 2 & 8 & 15 & 46 & 1 \\
\hline
\end{tabular}

TABLE II

INCIDENCE OF SEX CHROMOSOME ANOMALIES IN LIVE HOSPITAL BIRTHS

\begin{tabular}{|c|c|c|}
\hline Condition & $\begin{array}{c}\text { Incidence } \\
\text { per } \\
\text { Total Female } \\
\text { Births }\end{array}$ & $\begin{array}{l}\text { Incidence } \\
\text { per } \\
\text { Total Male } \\
\text { Births }\end{array}$ \\
\hline $\begin{array}{l}\text { Chromatin negative females } \\
\text { (1) XO or XO/Xx or chromo- } \\
\text { somes not examined } \\
\text { (2) XY. Testicular feminiza- } \\
\text { tion } \\
\text { (3) XY. Lipoid adrenal hyper- } \\
\text { plasia }\end{array}$ & 1 per 2758 & $\begin{array}{l}1 \text { per } 23,229 \\
1 \text { per } 23,229\end{array}$ \\
\hline $\begin{array}{l}\text { Chromatin positive females with } \\
\text { two masses }\end{array}$ & 1 per 1471 & \\
\hline $\begin{array}{l}\text { Chromatin positive males including } \\
\text { XXY, XY/XXY, XXYY, and } \\
\text { chromosomes not examined }\end{array}$ & & 1 per 504 \\
\hline $\begin{array}{l}\text { Chromatin positive males with two } \\
\text { masses }\end{array}$ & & 1 per 23,229 \\
\hline
\end{tabular}

Attempts are being made to follow up the remainder of the subjects on whom chromosome studies have not yet been done.

\section{Summary}

This paper presents sex chromatin findings in 9688 live hospital births, 4754 girls and 4934 boys. Among the girls, 2 have a proportion of cells with 2 sex chromatin masses and 5 are chromatin negative. Of the chromatin negative girls the 2 so far followed up both have XY sex chromosomes. One is a case of testicular feminization and the other had lipoid adrenal hyperplasia-an extremely rare condition due to a recessive gene. Among the boys one had a proportion of cells with 2 sex chromatin masses and 11 had a proportion of cells with one sex chromatin mass. Of the 11 boys with single masses, 2 had Down's syndrome. The association between sex chromosomal and autosomal aneuploidy is discussed. The data presented are combined with published data, and estimates of population incidence of the various conditions are given.

We acknowledge with thanks the advice and encouragement of Dr. A. White Franklin, Dr. A. P. Norman, Mr. T. L. T. Lewis, and the nursing staff at both hospitals. Helpful advice and discussion came from Professor P. E. Polani and Mr. J. L. Hamerton, and skilled technical aid from Miss S. Hunter, Miss B. Browne, Miss S. Midmer, and Mr. M. Curtis.

\section{REFERENCES}

Bergemann, E. (1961). Geschlechtschromatinbestimmungen am Neugeborenen. Schrveiz. med. Wschr., 91, 292.

Brown, W. M. C., Buckton, K. E., Jacobs, P. A., and Tough, I. M. (1964). The frequency of occurrence of subjects with karyotype abnormalities or variations. Hum. Chromos. Nezosl., 13, 10.

Hamerton, J. L., Giannelli, F., and Polani, P. E. (1965). Cytogenetics of Down's syndrome (mongolism). I. Data on a consecutive series of patients referred for genetic counselling and diagnosis. Cytogenetics, 4, 171.

Jagiello, G., and Atwell, J. D. (1962). Prevalence of testicular feminisation. Lancet, 1, 329.

Maclean, N., Harnden, D. G., Court Brown, W. M., Bond, J., and Mantle, D. J. (1964). Sex-chromosome abnormalities in newborn babies. ibid., 1, 286.

Marden, P. M., Smith, D. W., and McDonald, M. K. (1964). Congenital anomalies in the newborn infant, including minor variations. F. Pediat., 64, 357.

Moore, K. L. (1959). Sex reversal in newborn babies. Lancet, 1 , 217.

O'Doherty, N. J. (1964). Lipoid adrenal hyperplasia. Guy's Hosp. Rep., 113, 368.

Taylor, A. I. (1967). Patau's, Edwards' and cri du chat syndromes: A tabulated summary of current findings. Develop. Med. Child Neurol., 9, 78.

Wiesli, B. (1962). Comparison of phenotypical and nuclear sex in 3,029 neonates. Acta anat. (Basel), 51, 377. 